på samme måte som prosjekter som har til formål å fremskaffe ny viten om helse og sykdom. Avgrensningen helseforskningsloven opererer med, er ikke uten videre klar for mange av de involverte, med de problemer som dermed kan oppstå. Forskningsetikkloven anfører om regional etisk komités oppgaver: «Forskningsprosjekter i Norge som innebærer forsøk på mennesker, skal legges fram for komiteen til godkjenning.»

Helseforskningsloven, som er en spesiallov, vektlegger forskningens formål og inkluderer ikke forskningens subjekter, prosedyrer og intervensjoner. Helseforskningsloven ble innført for tre år siden og synes å ha fungert meget tilfredsstillende. Lorem \& Obstfelders erfaringer og andre saker som har vært diskutert i Den nasjonale forskningsetiske komité for medisin og helsefag kan likevel gi grunn til å ta en ny runde med diskusjon av plikten til fremlegging for regional etisk komité. Man kan vurdere endringer som åpner for å ta inn alle forskningsprosjekter som inkluderer forsøk på mennesker og alle prosjekter som inkluderer pasienter, uansett formål.

\section{Dag Bruusgaard}

dag.bruusgaard@medisin.uio.no

Dag Bruusgaard (f. 1940) er dr.med. og professor emeritus ved Institutt for helse og samfunn, Universitetet i Oslo. Han er leder av Den nasjonale forskningsetiske komité for medisin og helsefag (NEM).

Forfatter har fylt ut ICMJE-skjemaet og oppgir ingen interessekonflikter.

\section{Litteratur}

1. Lorem G, Obstfelder A. En forskningsetisk gråsone. Tidsskr Nor Legeforen 2012; 132: 1433

Publisert som rask respons i nettutgaven 20.9. 2012.

\section{G. Lorem \& A. Obstfelder svarer:}

Vårt innlegg tematiserte problemer knyttet til det å bli definert utenfor mandatet til helseforskningsloven. Ingen av de vedtakene vi bruker som eksempler er påklaget. Vi påstår altså ikke at regional etisk komité (REK) har vurdert dem feil, men tar beslutningene som avklaring av helseforskningslovens yttergrense. Vi peker på uklarheter og problemer som kan oppstå for prosjekter utenfor helseforskningsloven.

Vårt poeng er heller ikke at disse prosjektene faller inn i et «lovtomt rom». Vårt poeng er at det organ som vurderer prosjektene, må inneha den medisinske og helsefaglige kompetansen som helsefaglige prosjekter aktualiserer. Regional etisk komité sitter på både erfaring og kompetanse til å vurdere denne type prosjekter ut fra kjennskap til forskningsfeltet, alminnelige etiske prinsipper og god forskningspraksis. Ved at vi faller utenfor helseforskningslovens virkeområde, avskjæres vi som forskere fra muligheten til en dialog med en bredt sammensatt komité om forsvarligheten av vår forskning.

Vi mener forhåndsgodkjenning av prosjekter dreier seg om mer enn formalia. Spurkeland, representant i de nasjonale forskningsetiske komiteer (NESH) uttaler også i en kronikk hvor han mener de forskningsetiske komiteene bør bli mer synlige at «forskningen ville vært bedre og tilliten til forskningen større om flere forskningsprosjekter hadde blitt vurdert av komiteene» (1).

Vi spør om ikke alle prosjekter som involverer mennesker burde få like god etisk vurdering? Systemet med regionale etiske komiteer er etter hvert velprøvd. Vi etterspør tilsvarende bredt sammensatte komiteer for forskningsprosjekter som i dag ligger utenfor helseforskningsloven.

Hvis det er ønskelig med én postkasse, hvorfor ikke etablere et system der alle prosjekter med forsøkspersoner legges inn gjennom én felles portal i regi av de nasjonale forskningsetiske komiteer? Prosjekter kan deretter fordeles til de respektive komiteer for behandling. Hvis all forskning som inkluderer mennesker inngår $i$ et enhetlig og konsistent komitésystem, vil dette fjerne noen av de dilemmaene vi har beskrevet.

Vi innser det vil innebære en utvidelse av komitésystemet. I 2004 vurderte Utdannings- og forskningsdepartementet og Norsk samfunnsvitenskapelig datatjeneste (NSD) det slik at « ... det foreløpig ikke er behov for å etablere regionale komiteer under NESH og NENT» (2). Vi ønsker en ny debatt omkring dette. Det er derfor positivt at leder i Den nasjonale forskningsetiske komité for medisin og helsefag (NEM) ser en grunn til å ta en ny runde med diskusjon av fremleggingsplikten. Om det ikke er ønskelig å utvide komitésystemet, så er det nødvendig for å minimalisere gråsoneproblematikken at avgrensningene evalueres nøye.

\section{Geir Lorem}

geir.lorem@uit.no

Aud Obstfelder

Geir Lorem (f. 1969) er dr.art., førsteamanuensis ved Institutt for helse og omsorgsfag, Universitetet i Troms $\varnothing$, og medlem av Den nasjonale forskningsetiske komité for medisin og helsefag (NEM).

Forfatter har fylt ut ICMJE-skjemaet og oppgir ingen interessekonflikter.

Aud Obstfelder (f. 1965) er dr.polit. og førsteamanuensis ved Institutt for helse og omsorgsfag, Universitetet i Tromsø.

Forfatter har fylt ut ICMJE-skjemaet og oppgir ingen interessekonflikter.

\section{Litteratur}

1 Jacobsen SE. Komiteene bør bli mer synlig! Forskningsetiske komiteer www.etikkom.no/en/Aktuelt/Aktuelt/Fagbladet-Forskningsetikk/Arkiv/2010/ 2010-4/Komiteene-bor-bli-mer-synlige/ (15.2.2012).

2. Norsk samfunnsvitenskapelig datatjeneste (NSD). Høring - lovhjemling av etikkomiteer og nasjonalt utvalg for uredelighet i forskning. 7.10.2004. www.nsd.uib.no/personvern/doc/horing_041007.pdf (15.2.2012).

\section{God artikkel, men feil bilde}

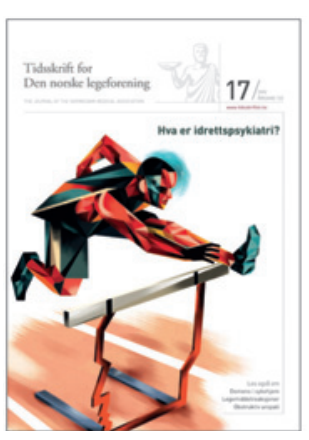

Jeg takker Kiarash Tazmini og medarbeidere for interessant artikkel i Tidsskriftet nr. 17/2012 (1), men teksten til figur 3 er feil (må være feil!). Alt i bildet tyder på at dette er et skann tatt kort etter intravenøs kontrast (kontrast i aorta, oppladning i milt, fylling av levervener/portagrener, kontrastoppladning i ventrikkelvegg etc.). Det blir derfor også meningsløst å sammenlikne tettheten i leverparenkymet på figur 2 og figur 3. Den sammenlikningen forteller oss i dette tilfellet ikke noe annet enn at leveren i figur 3 har fått kontrast. Dere burde altså ha brukt et annet bilde for å få frem poenget.

\section{Jon Heger}

jon.heger@lofotkraft.net

Jon Heger (f. 1949) er spesialist i radiologi ved Røntgenavdelingen,

Nordlandssykehuset - Lofoten

Ingen oppgitte interessekonflikter.

\section{Litteratur}

1. Tazmini K, Bakken HN, Schjesvold FH. En kvinne i 70-årene med redusert allmenntilstand, dyspné og utbredte smerter. Tidsskr Nor Legeforen 2012; 132 $1969-72$.

Publisert som rask respons i nettutgaven 24.9. 2012. 